https://doi.org/10.15407/ujpe63.12.1113

\title{
OLEKSANDR PANTELEIMONOVYCH RUDENKO (to the 80th anniversary of his birthday)
}

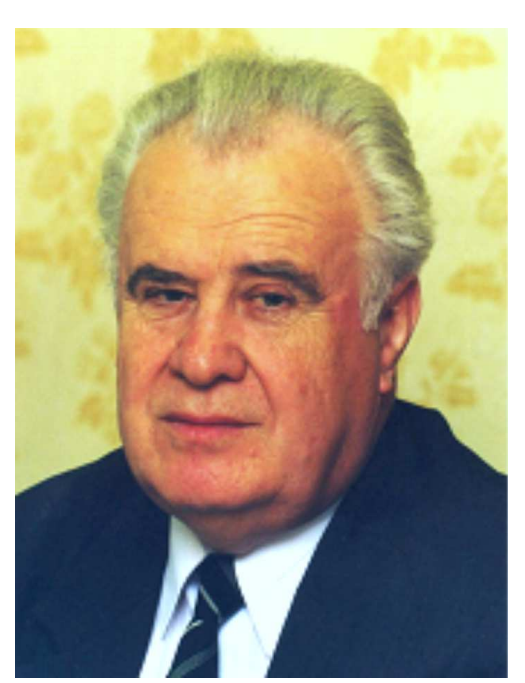

December 29, 2018 is the 80th birthday of the famous Ukrainian physicist, Honored Worker of Ukraine in science and engineering, Academician of the Academy of Sciences of the Higher School of Ukraine in the Branch of Physics and Astronomy, Professor of V.P. Korolenko National Pedagogical University of Poltava Oleksandr Panteleimonovych Rudenko.

Oleksandr Panteleimonovych was born in 1938 at the hamlet of Chekysyn, the Lubny district of the Poltava region. In 1963, after graduating from the Poltava Pedagogical Institute (PPI) in the specialty "Physics and Fundamentals of Fabrication", he began to work as a teacher of physics at the secondary school No. 6 in Poltava. From 1968, he worked as an assistant at the Department of General Physics of the PPI.

In 1972-1975, Oleksandr Panteleimonovych was a post-graduate student at the Department of Molecular Physics of the T.G. Shevchenko State University of Kyiv. In 1977, he defended his Ph.D. thesis "Re-

ISSN 2071-0194. Ukr. J. Phys. 2018. Vol. 63, No. 12 search of elastic and viscous properties of molecular liquids" in the specialty 01.04.14 (thermal physics and molecular physics) and obtained the Ph.D. degree in physics and mathematics.

Having returned to his native Poltava, from 1978 to 2003, he was the Dean of the Faculty of Physics and Mathematics at the PPI. In 1980-1991, he was the Associate Professor of the Department of General Physics and, from 1992, the Head of this Department. The same year, Oleksandr Panteleimonovych he was awarded the title of Professor of the Department of General Physics. In 1993, O.P. Rudenko defended his doctoral dissertation "Molecular mechanisms of nonequilibrium processes in a number of homogeneous and heterogeneous liquid systems" in the specialty 01.04.14 (thermal physics and molecular physics) and obtained the Dr.Sci. degree in physics and mathematics. In 1998, O.P. Rudenko became Academician of the Academy of Sciences of the Higher School of Ukraine in the Branch of physics and astronomy. Since 2011 and till now, he is working as the Head of the Department of General Physics and Mathematics at V.G. Korolenko National Pedagogical University of Poltava.

The scientific interests of O.P. Rudenko are mainly focused on the problems of the physics of fluids and liquid systems. Professor O.P. Rudenko manages the researches in the field of acoustic, rheological, dielectric, and thermophysical properties of fluorinated organic fluids and binary liquid systems (water and non-aqueous solutions of biological objects, polyols, polymers, and so forth). He is a founder of the scientific school "Acoustic Spectroscopy of Condensed Systems". Under the direction of Professor Rudenko, a hyperacoustic installation for measuring the propagation velocity and the absorption coefficient of ultrasound in a wide range of frequencies and temperatures

1113 
was developed. For two decades, this installation remained one of the best in the world.

The interests of O.P. Rudenko also include the actual problems of lecturing physics and astronomy at higher and secondary schools. In 1995, a postgraduate course in the specialty 01.04.14 (thermal physics and molecular physics) was created at the Department of General Physics and Mathematics. Under the scientific supervision of Professor O.P. Rudenko, eight Ph.D. theses were defended. They were devoted to the acoustic spectroscopy of liquid polyesters (Yu.P. Bendes, Ya.V. Sperkach, O.M. Tyutyunnyk, and S.O. Sperkach), the acoustic spectroscopy of aqueous solutions of nitrates of doubly charged cations (L.O. Matyash), the acoustic and rheological properties of fluorinated aromatic compounds (A.M. Khlopov), the rheological and dielectric properties of flexible-chain polymer solutions (O.V. Khorolskyi), and the methods of teaching physics (G.M. Kuzmenko).

Professor O.P. Rudenko is an author of more than 100 scientific papers on the physics of fluids and liquid systems, which were published in leading professional journals, several hundreds of methodological developments and monographs on physics and the history of physics, engineering, and space science. O.P. Rudenko has patents for many inventions, among which there is a "Method for diagnosing inflammatory complications after surgical treatment of stomach cancer" (1997), a "Method for controlling the endotoxicosis development" (1999), a "Method of organizing a physical experiment" (2011), and a "Device for measuring the viscosity of liquid substances" (2016). On his initiative, the department fulfils the scientific and research theme "Research of physical and chemical properties of binary systems in the condensed state".
On the initiative of Professor O.P. Rudenko and under his management, annual all-Ukrainian scientific and practical conferences are held, in particular, All-Ukrainian readings to the memory of Yu.V. Kondratyuk.

For his productive scientific work and significant achievements in the field of education, Professor O.P. Rudenko was awarded the sign Excellent Worker in education (1983), the Honorary Diploma of the Ministry of Education of Ukraine (1994), the Diploma of the Poltava Regional Council (2013), and many medals.

Professor O.P. Rudenko is not only a well-known scientist and a lecturer at the institution. He also became, in a sense, a curator of the refined Ukrainian language and culture in the Poltava region. Even during the worst times of Bolsheviks' preponderance, he communicated with his students and disciples, as well as colleagues, exclusively in the melodious Ukrainian language. As a result, almost everybody from those with whom he communicated spoke this language: Armenians, Russians, Moldavians... Plenty of glorious names were brought back to the Poltava region owing to persistent efforts of Oleksandr Panteleimonovych!

We sincerely congratulate Oleksandr Panteleimonovych on his jubilee and wish him good health, new achievements, and talented students who will continue the matter of his life.

L. BULAVIN, P. CHOLPAN, YU. ZABASHTA, M. KULISH, O. CHALYI, V. SYSOEV, L. POPERENKO, O. ALEKSEEV, M. MALOMUZH, O. SVECHNIKOVA, YU. MOSKALENKO, O. KHOROLSKYI 